\title{
MOVAS-1 cell line: A new in vitro model of vascular calcification
}

\author{
N.C.W. MACKENZIE, D. ZHU, L. LONGLEY, C.S. PATTERSON, S. KOMMAREDDY and V.E. MacRAE
}

The Roslin Institute and Royal (Dick) School of Veterinary Studies, University of Edinburgh, Roslin Biocentre, Roslin, UK

Received December 21, 2010; Accepted January 28, 2011

DOI: $10.3892 / \mathrm{ijmm} .2011 .631$

\begin{abstract}
Vascular calcification has severe clinical consequences in a number of diseases, including diabetes, atherosclerosis and end-stage renal disease. The in vitro calcification of primary mouse, human and bovine vascular smooth muscle cells (VSMCs) is commonly employed to examine the mechanisms of vascular calcification. However, to date, no published studies have utilised a murine cell line to investigate this process. In the present study, we aimed to determine whether the mouse VSMC line MOVAS-1 can calcify in vitro. We established that the calcification of MOVAS-1 cells can be induced in the presence of calcifying medium (containing $\beta$-glycerophosphate and ascorbic acid), as detected by Alizarin Red and von Kossa staining, and quantification of calcium deposition and alkaline phosphatase activity. We also showed that the time course of MOVAS-1 calcification is comparable to that of the primary murine aortic VSMCs, establishing the MOVAS-1 cells as a feasible and relevant model. Significant increases in the mRNA expression profile of key genes associated with vascular calcification $(O c n, A k p 2$ and $P i T-1)$ were observed in MOVAS-1 cells cultured under calcifying conditions, with similar changes in expression in murine aortic VSMCs. Furthermore, a significant reduction in calcification was observed in MOVAS-1 cells following treatment with levamisole and etidronate, known inhibitors of calcification. In conclusion, we demonstrated that the MOVAS-1 line is a reliable, convenient and economical system in which to investigate vascular calcification in vitro, and will make a useful contribution to increasing our understanding of this pathological process.
\end{abstract}

\section{Introduction}

Vascular calcification has severe clinical consequences in a number of diseases, including diabetes, atherosclerosis and endstage renal disease (1-3). The process of vascular calcification

Correspondence to: Dr V.E. MacRae, The Roslin Institute and Royal (Dick) School of Veterinary Studies, University of Edinburgh, Roslin Biocentre, Roslin, Midlothian EH25 9PS, UK

E-mail: vicky.macrae@roslin.ed.ac.uk

Key words: vascular calcification, MOVAS-1, vascular smooth muscle cells, mouse shares many similarities with that of bone formation, which occurs through osteoblast and chondrocyte extracellular matrix calcification $(1,2)$. Vascular smooth muscle cells (VSMCs), the predominant cell type involved in vascular calcification, can undergo phenotypic transition to calcifying osteoblastic and chondrocytic cells in a calcified environment (4-8). Drivers of VSMC chondro-osseous differentiation and calcification include mineral imbalance; bone morphogenic proteins (BMPs); certain oxidised pro-atherogenic lipids and loss of negative regulators of calcification $(2,4,5,7-16)$. The phosphate transporter, PiT-1, is the predominant sodiumdependent phosphate co-transporter expressed in VSMCs. Increased PiT-1 expression leads to elevated intracellular phosphate, which induces the osteogenic conversion of VSMCs (17). Tissue non-specific alkaline phosphatase (ALP), a key regulator of bone calcification, also plays an important role in vascular calcification through the generation of phosphate, and by reducing levels of the calcification inhibitor pyrophosphate in blood vessels $(18,19)$.

The in vitro calcification of primary mouse $(20,21)$, human $(22,23)$ and bovine $(4,24-26)$ VSMCs are commonly utilised models of vascular calcification. Cells derived from transgenic mouse models with vascular calcification phenotypes are also frequently studied $(7,18,27)$. However, to date, no published studies have utilised a murine cell line to investigate vascular calcification.

The mouse VSMC line MOVAS-1 was initially described by Afroze et al (28). This cell line exhibits a smooth muscle cell-specific phenotype, and has been employed to investigate the VSMC cell cycle (28); neuroendocrine peptide expression profiles (29); vascular circadian rhythms (30) and signal transduction responses to cytokines (31).

This cell line offers an alternative to primary cells derived directly from animals, reducing experimental variation and allowing stable transformation of VSMCS. The present study has therefore evaluated the MOVAS-1 cell line as an in vitro model of vascular calcification.

\section{Materials and methods}

MOVAS-1 cell culture. MOVAS-1 cells were a kind gift from Professor M. Hussein, Univeristy of Toronto, Canada. Cells were maintained in DMEM (Invitrogen, Paisley, UK) supplemented with 10\% FCS (Invitrogen) and 1\% gentamycin (Invitrogen). Cells were seeded in multi-well plates (Costar, High Wycombe, Bucks, UK) at a density of $1.0 \times 10^{4}$ cells $/ \mathrm{cm}^{2}$. At confluence, the medium was supplemented with $2.5 \mathrm{mM}$ 
$\beta$-glycerophosphate ( $\beta$ GP) (Sigma, Poole, Dorset, UK) and $50 \mu \mathrm{g} / \mathrm{ml}$ ascorbic acid (Sigma) for 21 days to induce calcification. Cells were exposed to $1-100 \mu \mathrm{g} / \mathrm{ml}$ etidronate (Sigma) or to $0.01-1 \mathrm{mM}$ levamisole (Sigma). Incubation was performed at $37^{\circ} \mathrm{C}$ in a humidified atmosphere of $95 \%$ air $/ 5 \% \mathrm{CO}_{2}$ and the medium was changed every second/third day.

Primary murine VSMC isolation. Primary VSMCs were isolated from aortas dissected from C57Bl6 mice at 5 weeks of age. The adventitia was removed and the aorta cut open to expose the endothelial layer (7). Tissues from eight animals were pooled for digestion with $1 \mathrm{mg} / \mathrm{ml}$ trypsin to remove remaining adventitia and endothelium, followed by incubation overnight at $37^{\circ} \mathrm{C}$ in a humidified atmosphere of $95 \%$ air $/ 5 \%$ $\mathrm{CO}_{2}$ in growth medium consisting of $\alpha$-MEM supplemented with $10 \%$ FCS and $1 \%$ gentamycin. Tissues were then digested in $425 \mathrm{U} / \mathrm{ml}$ collagenase type II for $5 \mathrm{~h}$. Before experimentation, isolated VSMCs were expanded in growth medium for two passages in T25 tissue-culture flasks (Greiner Bio-One $\mathrm{GmbH}$, Frickenhausen, Baden-Württemberg, Germany) coated with $0.25 \mu \mathrm{g} / \mathrm{cm}^{2}$ murine laminin (Sigma) to promote maintenance of the contractile differentiation state (32).

Primary murine VSMC culture. VSMCs were seeded at a density of $1.5 \times 10^{4}$ cells $/ \mathrm{cm}^{2}$. At confluence, growth medium supplemented with $2.5 \mathrm{mM} \beta \mathrm{GP}$ and $50 \mu \mathrm{g} / \mathrm{ml}$ ascorbic acid for 21 days to induce calcification. Cells were incubated was at $37^{\circ} \mathrm{C}$ in a humidified atmosphere of $95 \%$ air $/ 5 \% \mathrm{CO}_{2}$ and the medium was changed every second/third day.

Detection of calcification. Calcium deposition was evaluated by staining the cell-matrix monolayer with Alizarin Red $(33,34)$. Cells were washed twice with phosphate buffered saline, fixed in $4 \%$ paraformaldehyde for $5 \mathrm{~min}$ at $4^{\circ} \mathrm{C}$, stained with $2 \%$ Alizarin Red (pH 4.2) for $5 \mathrm{~min}$ at room temperature and rinsed with distilled water. Alizarin Red-stained cultures were extracted with $10 \%$ cetylpyridium chloride for $10 \mathrm{~min}$. The OD was determined at $570 \mathrm{~nm}$ using a spectrophotometer (Multiskan Ascent, Thermo Electron Corporation, Vantaa, Finland). To investigate phosphate deposition, von Kossa staining was undertaken (32). Cells were fixed in $4 \%$ paraformaldehyde for $5 \mathrm{~min}$ at $4^{\circ} \mathrm{C}$, stained with $5 \%$ silver nitrate solution for $20 \mathrm{~min}$ and fixed in $5 \%$ sodium thiosulphate solution for $5 \mathrm{~min}$.

The matrix was decalcified in $0.6 \mathrm{~N} \mathrm{HCl}$ for $24 \mathrm{~h}$, and free calcium was determined colorimetrically using a commercially available kit (Randox Laboratories Ltd., Crumlin, UK) and corrected for total protein concentration. The protein content of the cells was measured using the Bio-Rad protein assay reagent (Bio-Rad Laboratories, Hertfordshire, UK) based on the Bradford dye binding procedure, and $\gamma$-globulin was used as standard (35).

Alkaline phosphatase (ALP) activity. Cell layers were lysed with $0.9 \% \mathrm{NaCl}$ and $0.2 \%$ Triton $\mathrm{X}-100$ and centrifuged at $12,000 \mathrm{xg}$ for $15 \mathrm{~min}$ at $4^{\circ} \mathrm{C}$. The supernatant was assayed for protein content and ALP activity. Enzyme activity was determined by measuring the cleavage of $10 \mathrm{mM}$ p-nitrophenyl phosphate (pNPP) at $410 \mathrm{~nm}$ using a commercially available kit (Thermo Trace, Melbourne, Australia). Total ALP activity was expressed as nmoles pNPP hydrolysed/min/mg protein (36).

Analysis of SM22 $\alpha$ expression using semi-quantitative $R T-P C R$. RNA was extracted from cells using RNeasy total RNA (Qiagen Ltd., Crawley, UK), according to the manufacturer's instructions. For each sample, total RNA content was assessed by absorbance at $260 \mathrm{~nm}$ and purity by A260/A280 ratios. RNA was reverse transcribed and the PCR reaction undertaken as described previously $(37,38)$. For the PCR reaction, primers for $18 S$ rRNA gene ( 20 cycles) (Ambion, Huntingdon, UK, sequence not disclosed) and SM22 $\alpha$ (35 cycles) (Forward 5'TCC AGT CCA CAA ACG ACC AAG C3', Reverse 5'GAA TTG AGC CAC CTG TTC CAT CTG-3') were used.

Analysis of gene expression using quantitative RT-PCR. RNA was extracted, quantified and reverse transcribed as described above. RT-qPCR was performed using the Stratagene Mx3000P real-time QPCR system (Stratagene, CA, USA). Primers for PiT- 1 (Forward, 5'CAC TCA TGT CCA TCT CAG ACT3'; Reverse, 5'CGT GCC AAA GAA GGT GAA C3'), Osteocalcin (Ocn) (Forward, 5'CCG GGA GCA GTG TGA GCT TA3'; Reverse, 5' TAG ATG CGT TTG TAG GCG GTC 3'), ALP (Akp2) (Forward, 5'GGG ACG AAT CTC AGG GTA CA3'; Reverse 5'AGT AAC TGG GGT CTC TCT CTT T3') and Gapdh (sequence not disclosed) were used (Primer Design, Southampton, UK).

Statistical analysis. General Linear Model analysis and the Student's t-test were used to assess the data. All data are expressed as the mean \pm SEM. Statistical analysis was performed using Minitab 15. $\mathrm{P}<0.05$ was considered to be significant.

\section{Results}

Calcification of MOVAS-1 cells. Initial studies were undertaken to determine whether the calcification of MOVAS-1 cells could be induced, when cultured in the presence of calcifying medium (containing $\beta$ GP and ascorbic acid). At 21 days, Alizarin Red (Fig. 1A) and von Kossa (Fig. 1B) staining confirmed the deposition of calcium and phosphate, respectively. Calcium deposition was quantified following decalcification in $0.6 \mathrm{M} \mathrm{HCl}$, and was significantly increased $(\mathrm{P}<0.001$; Fig. 1C). The activity of ALP, a molecule known to play an important role in vascular calcification $(18,19)$, was also significantly elevated $(\mathrm{P}<0.001$; Fig. 1D).

Further studies were performed to evaluate the utilisation of MOVAS- 1 cells as a model of in vitro calcification. The time course of MOVAS- 1 calcification was examined, and compared to that of murine aortic VSMCs. Alizarin Red staining in MOVAS-1 cells cultured under calcifying conditions was negligible at 0 days, with significant increases in staining intensity at 7, 14 and 21 days $(\mathrm{P}<0.01$; Fig. $2 \mathrm{~B})$. Comparable increases in Alizarin Red staining in murine VSMCs were observed ( $\mathrm{P}<0.01$; Fig. 2A). ALP activity in MOVAS-1 cells was also significantly increased at 7,14 and 21 days compared to 0 days $(\mathrm{P}<0.01$; Fig. 2D). Comparable increases in ALP activity in murine VSMCs were observed $(\mathrm{P}<0.01 ;$ Fig. $2 \mathrm{C})$. 

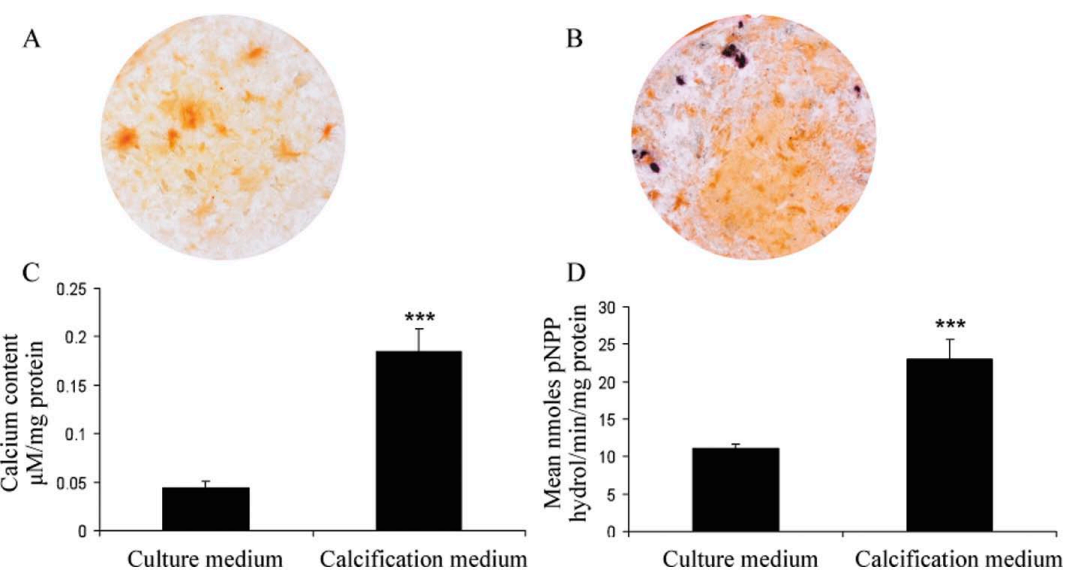

Figure 1. In vitro calcification of MOVAS-1 cells. (A) Alizarin Red staining showing calcium deposition and (B) von Kossa staining showing phosphate deposition in MOVAS-1 cells cultured for 21 days under calcifying conditions. (C) Calcium content $(\mu \mathrm{M} / \mathrm{mg}$ protein) and (D) alkaline phosphatase activity (mean moles pNPP hydrol/min/mg protein) of MOVAS-1 cells cultured in the presence or absence of calcifying conditions.

A

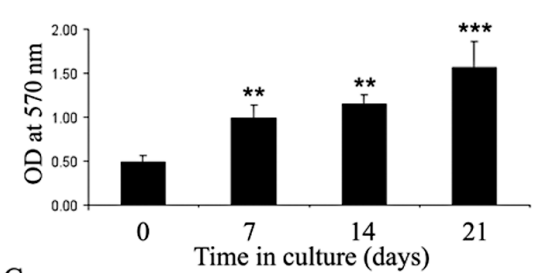

$\mathrm{C}$

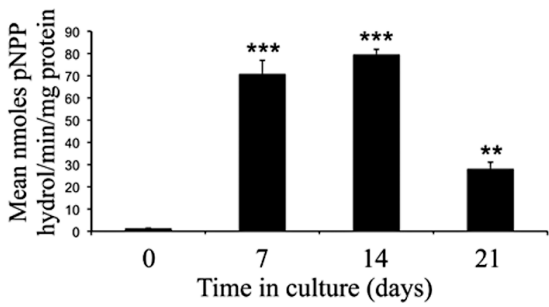

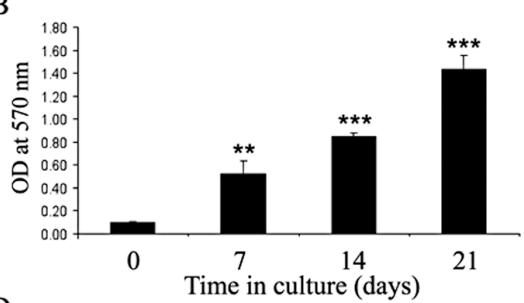

$\mathrm{D}$

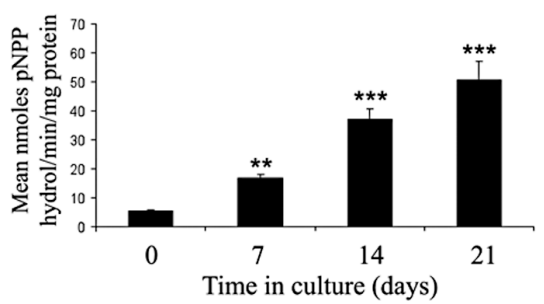

Figure 2. Quantification of Alizarin Red staining showing calcium deposition in (A) murine VSMCs and (B) MOVAS-1 cells cultured for 21 days under calcifying conditions. Quantification of alkaline phosphatase activity (mean moles pNPP hydrol/min/mg protein) in (C) murine VSMCs and (D) MOVAS-1 cells cultured for 21 days under calcifying conditions.

A

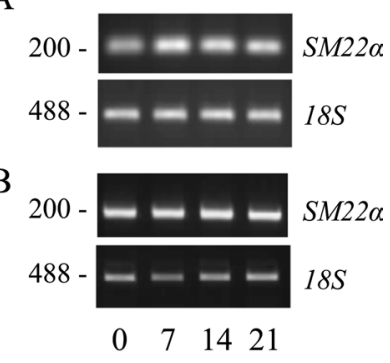

Time in culture

(days)

Figure 3. Semi-quantitative RT-PCR analysis of SM22 $\alpha$ and $18 \mathrm{~S}$ expression in (A) murine VSMCs and (B) MOVAS-1 cells cultured for 21 days under calcifying conditions.

Changes in gene expression in calcifying MOVAS-1 cells. In order to verify that MOVAS-1 cells and murine aortic VSMCs maintained a VSMC phenotype throughout the culture period, the expression of the VSMC marker SM22 $\alpha$ was confirmed by semi-quantitative PCR (Fig. 3). Further gene expression studies were undertaken, to investigate the expression profile of key genes associated with vascular calcification in MOVAS-1 cells, compared to murine aortic VSMCs. Quantitative PCR revealed significant increases $(\mathrm{P}<0.05)$ in the expression of Ocn (Fig. 4B), Akp2 (Fig. 4D) and PiT-1 (Fig. 4F) in MOVAS-1 cells cultured under calcifying conditions, with similar changes in the expression in murine aortic VSMCs (Fig. 4A, C and E, respectively). These data suggest that the culture of MOVAS-1 cells in a calcifying medium is an appropriate model with which to study vascular calcification in vitro.

Inhibition of MOVAS-1 calcification by etidronate and levamisole. These studies have established that MOVAS-1 cells undergo calcification with associated changes in gene expression comparable to that of murine aortic VSMCs. Further experiments investigated whether this calcification of MOVAS-1 cells could be reduced, using known inhibitors of calcification over a 21-day culture period. 

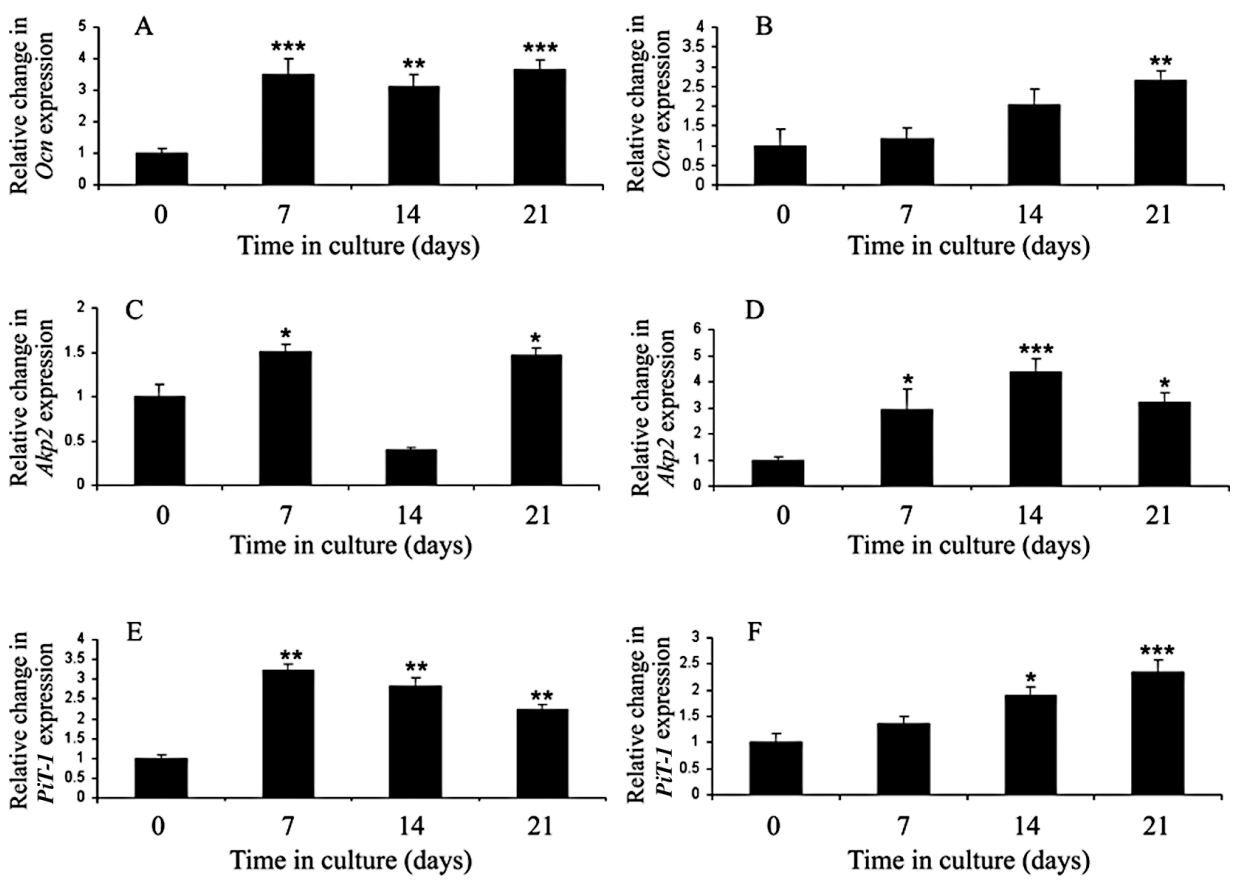

Figure 4. Fold changes in mRNA expression during culture for 21 days under calcifying conditions of $O c n$ in (A) murine VSMCs and (B) MOVAS-1 cells; Akp2 in (C) murine VSMCs and (D) MOVAS-1 cells and PiT-1 in (E) murine VSMCs and (F) MOVAS-1 cells.

A
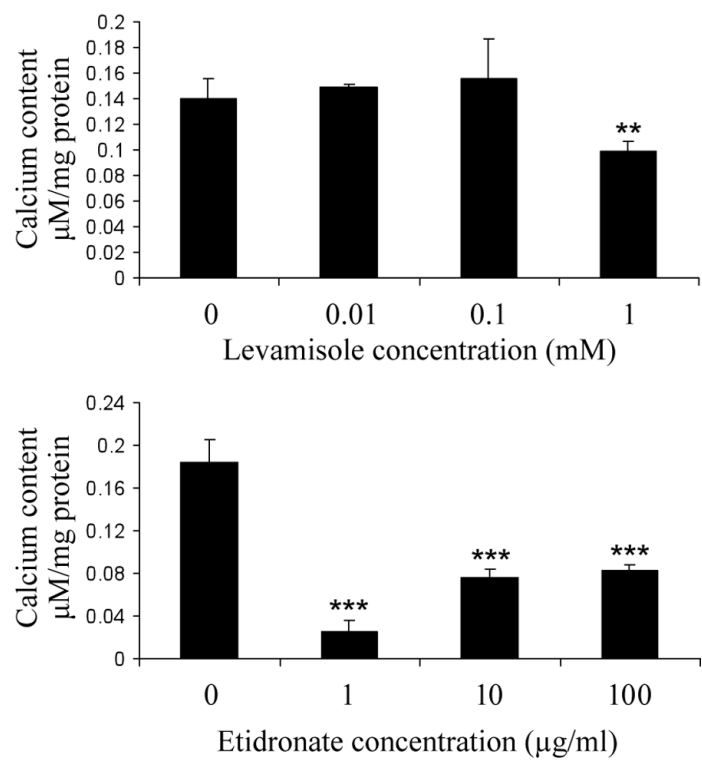

Figure 5. Effect of (A) levamisole (0.01-1 mM) and (B) etidronate (1-100 $\mu \mathrm{g} / \mathrm{ml})$ exposure on MOVAS-1 calcification in vitro, following culture for 21 days under calcifying conditions.

The effect of levamisole (0.01-1 mM), a specific inhibitor of ALP (39), on MOVAS-1 calcification was determined. A significant reduction in calcium deposition $(\mathrm{P}<0.01)$ was observed following exposure to $1 \mathrm{mM}$ levamisole (Fig. 5A). These data confirm the functional significance of ALP in the calcification process.

As the production of hydroxyapatite is involved in vascular calcification, we also examined the effects of the bisphosphonate etidronate (1-100 $\mu \mathrm{g} / \mathrm{ml})$, a known inhibitor of hydroxyapatite formation (40), on MOVAS-1 calcification (Fig. 5B). A significant reduction in calcium deposition $(\mathrm{P}<0.01)$ was observed following exposure to 1,10 and $100 \mu \mathrm{g} / \mathrm{ml}$ etidronate. These results demonstrate the formation of hydroxyapatite by MOVAS-1 cells, and confirm the inhibitory effect of etidronate on vascular calcification in vitro.

\section{Discussion}

The in vitro calcification of mouse $(20,21)$, human $(22,23)$ and bovine $(4,24-26)$ vascular smooth muscle cells (VSMCs) are a commonly employed model of vascular calcification. However, primary VSMC cultures exhibit slow growth and cannot be used beyond a limited number of passages due to senescence and phenotypic changes that occur during culture. Furthermore, the use of primary cells is labour-intensive, expensive, and time-consuming (28). Moreover, the utilisation of an immortalized mouse VSMC line in the field of vascular calcification would allow complementary in vitro studies of mouse models in which transgenic manipulations and their effects are restricted to VSMCs in vivo $(41,42)$. For these reasons, we characterized the in vitro calcification of the mouse VSMC cell line, MOVAS-1.

Since the establishment of the MOVAS-1 cell line (28), these cells have been utilised in vascular studies that have investigated the cell cycle (28), neuroendocrine peptide expression profiles (29), circadian rhythms (30) and signal transduction responses (31). However, to date, no published studies have employed the MOVAS-1 cell line to investigate vascular calcification.

In the present study, we showed that the calcification of MOVAS-1 cells can be induced in the presence of calcifying medium containing $\beta$ GP and ascorbic acid. This was demonstrated through standard staining and enzyme activity assays frequently employed to assess vascular calcification in vitro $(7,18,32)$. 
We also showed that the time course of MOVAS-1 calcification is comparable to that of primary murine aortic VSMCs, establishing that MOVAS-1 cells are a feasible and relevant model. Furthermore, calcified MOVAS- 1 cells showed increased expression of a number of recognized markers of vascular calcification including PiT-1, ALP and Ocn. The phosphate transporter PiT-1 is the predominant sodium-dependent phosphate co-transporter expressed in VSMCs. Increased PiT-1 expression leads to elevated intracellular phosphate and induces the osteogenic conversion of VSMCs (17). Conversely, down-regulation of PiT-1 gene expression by RNA knockdown has been shown to reduce phosphate uptake by VSMCs and inhibit phosphate-induced VSMC phenotypic transition and calcification (17). ALP, a key regulator of bone calcification, also plays an important role in vascular calcification through the generation of phosphate, and by decreasing levels of PPi in blood vessels $(18,19)$. $O c n$ is a vitamin K-dependent matrix protein proposed to be involved in the regulation of calcium crystal development (43). Our data therefore suggest that the culture of MOVAS-1 cells in a calcifying medium is an appropriate model with which to study vascular calcification in vitro.

Using known molecular inhibitors, we also demonstrated that functional studies can be undertaken in MOVAS-1 cells. Levamisole reversibly but non-competitively inhibits ALP (39), and is a potent inhibitor of the calcification of osteoblasts (bone forming cells) $(44,45)$ and VSMCs $(19,46)$. The bisphosphonate etidronate, an inhibitor of hydroxyapatite formation, has also been reported to inhibit calcification of VSMCs and osteoblasts. The reduction in calcification observed in MOVAS-1 cells following treatment with levamisole and etidronate confirms that this cell line is highly applicable to vascular calcification research.

The severe clinical implications of vascular calcification are widely recognized. However, the underlying mechanisms have yet to be fully elucidated and effective therapeutic strategies that may prevent and potentially reverse vascular calcification are not currently available. The MOVAS-1 cell line is a reliable, convenient and economical system in which to investigate vascular calcification in vitro, and will make a useful contribution to increasing our understanding of this pathological process.

\section{Acknowledgements}

This study was supported by a Wellcome Trust CVRT award, an Institute Strategic Programme Grant from the Biotechnology and Biological Sciences Research Council (BBSRC) and Institute Career Path Fellowship funding from the BBSRC.

\section{References}

1. Shroff RC and Shanahan CM: The vascular biology of calcification. Semin Dial 20: 103-109, 2007.

2. Demer LL and Tintut Y: Vascular calcification: pathobiology of a multifaceted disease. Circulation 117: 2938-2948, 2008.

3. Schenker MP, Dorbala S, Hong ECT, Rybicki FJ, Hachamovitch R, Kwong RY and Di Carli MF: Interrelation of coronary calcification, myocardial ischemia, and outcomes in patients with intermediate likelihood of coronary artery disease: a combined positron emission tomography/computed tomography study. Circulation 117: 1693-1700, 2008.
4. Steitz SA, Speer MY, Curinga G, Yang HY, Haynes P, Aebersold R, Schinke T, Karsenty G and Giachelli CM: Smooth muscle cell phenotypic transition associated with calcification: upregulation of Cbfa1 and downregulation of smooth muscle lineage markers. Circ Res 89: 1147-1154, 2001.

5. Abedin M, Tintut $\mathrm{Y}$ and Demer LL: Vascular calcification: mechanisms and clinical ramifications. Arterioscler Thromb Vasc Biol 24: 1161-1170, 2004.

6. Yang H, Curinga G and Giachelli CM: Elevated extracellular calcium levels induce smooth muscle cell matrix mineralization in vitro. Kidney Int 66: 2293-2299, 2004.

7. Johnson K, Polewski M, van Etten D and Terkeltaub R: Chondrogenesis mediated by $\mathrm{PP}_{\mathrm{i}}$ depletion promotes spontaneous aortic calcification in NPP1-/- mice. Arterioscler Thromb Vasc Biol 25: 686-691, 2005.

8. Speer MY, Chien YC, Quan M, Yang HY, Vali H, McKee MD and Giachelli CM: Smooth muscle cells deficient in osteopontin have enhanced susceptibility to calcification in vitro. Cardiovasc Res 66: 324-333, 2005.

9. Towler DA, Bidder M, Latifi T, Coleman T and Semenkovich CF: Diet-induced diabetes activates an osteogenic gene regulatory program in the aortas of low density lipoprotein receptordeficient mice. J Biol Chem 273: 30427-30434, 1998.

10. Tintut Y, Alfonso Z, Saini T, Radcliff K, Watson K, Boström K and Demer LL: Multilineage potential of cells from the artery wall. Circulation 108: 2505-2510, 2003.

11. Reynolds JL, Joannides AJ, Skepper JN, McNair R, Schurgers LJ, Proudfoot D, Jahnen-Dechent W, Weissberg PL and Shanahan CM: Human vascular smooth muscle cells undergo vesicle-mediated calcification in response to changes in extracellular calcium and phosphate concentrations: a potential mechanism for accelerated vascular calcification in ESRD. J Am Soc Nephrol 15: 2857-2867, 2004.

12. Alexander MY, Wilkinson FL, Kirton JP, Rock CF, Collett GD, Jeziorska M, Smyth JV, Heagerty AM and Canfield AE: Identification and characterization of vascular calcificationassociated factor, a novel gene upregulated during vascular calcification in vitro and in vivo. Arterioscler Thromb Vasc Biol 25: 1851-1857, 2005.

13. Shao JS, Cheng SL, Pingsterhaus JM, Charlton-Kachigian N, Loewy AP and Towler DA: Msx2 promotes cardiovascular calcification by activating paracrine Wnt signals. J Clin Invest 115: 1210-1220, 2005.

14. Murshed M, Harmey D, Millán JL, McKee MD and Karsenty G: Unique coexpression in osteoblasts of broadly expressed genes accounts for the spatial restriction of ECM mineralization to bone. Genes Dev 19: 1093-1104, 2005.

15. Aikawa E, Nahrendorf M, Figueiredo JL, Swirski FK, Shtatland T, Kohler RH, Jaffer FA, Aikawa M and Weissleder R: Osteogenesis associates with inflammation in early-stage atherosclerosis evaluated by molecular imaging in vivo. Circulation 116: 2030-2034, 2008 .

16. Shroff RC, McNair R, Figg N, Skepper JN, Schurgers L, Gupta A, Hiorns M, Donald AE, Deanfield J, Rees L and Shanahan CM: Dialysis accelerates medial vascular calcification in part by triggering smooth muscle cell apoptosis. Circulation 118: 1748-1757, 2008.

17. Li X, Yang HY and Giachelli CM: Role of the sodium-dependent phosphate cotransporter, PiT-1, in vascular smooth muscle cell calcification. Circ Res 98: 905-912, 2006.

18. Narisawa S, Harmey D, Yadav MC, O'Neill WC, Hoylaerts MF and Millán JL: Novel inhibitors of alkaline phosphatase suppress vascular smooth muscle cell calcification. J Bone Miner Res 22: 1700-1710, 2007.

19. Lomashvili KA, Garg P, Narisawa S, Millan JL and O'Neill WC: Upregulation of alkaline phosphatase and pyrophosphate hydrolysis: potential mechanism for uremic vascular calcification. Kidney Int 73: 1024-1030, 2008.

20. Byon CH, Javed A, Dai Q, Kappes JC, Clemens TL, DarleyUsmar VM, McDonald JM and Chen Y: Oxidative stress induces vascular calcification through modulation of the osteogenic transcription factor Runx2 by AKT signaling. J Biol Chem 283: 15319-15327, 2008.

21. Huang MS, Sage AP, Lu J, Demer LL and Tintut Y: Phosphate and pyrophosphate mediate PKA-induced vascular cell calcification. Biochem Biophys Res Commun 374: 553-558, 2008.

22. Schurgers LJ, Spronk HM, Skepper JN, Hackeng TM, Shanahan CM, Vermeer C, Weissberg PL and Proudfoot D: Post-translational modifications regulate matrix Gla protein function: importance for inhibition of vascular smooth muscle cell calcification. J Thromb Haemost 5: 2503-2511, 2007. 
23. Ewence AE, Bootman M, Roderick HL, Skepper JN, McCarthy G, Epple M, Neumann M, Shanahan CM and Proudfoot D: Calcium phosphate crystals induce cell death in human vascular smooth muscle cells: a potential mechanism in atherosclerotic plaque destabilization. Circ Res 103: E28-E34, 2008.

24. Shioi J, Pangalos MN, Ripellino JA, Vassilacopoulou D, Mytilineou C, Margolis RU and Robakis NK: The Alzheimer amyloid precursor proteoglycan (appican) is present in brain and is produced by astrocytes but not by neurons in primary neural cultures. J Biol Chem 270: 11839-11844, 1995.

25. Collett GD, Sage AP, Kirton JP, Alexander MY, Gilmore AP and Canfield AE: Axl/phosphatidylinositol 3-kinase signaling inhibits mineral deposition by vascular smooth muscle cells. Circ Res 100: 502-509, 2007.

26. Alam MU, Kirton JP, Wilkinson FL, Towers E, Sinha S, Rouhi M, Vizard TN, Sage AP, Martin D, Ward DT, Alexander MY, Riccardi D and Canfield AE: Calcification is associated with loss of functional calcium-sensing receptor in vascular smooth muscle cells. Cardiovasc Res 81: 260-268, 2009.

27. Luo G, Ducy P, McKee MD, Pinero GJ, Loyer E, Behringer RR and Karsenty G: Spontaneous calcification of arteries and cartilage in mice lacking matrix GLA protein. Nature 386: 78-81, 1997.

28. Afroze T, Yang LL, Wang C, Gros R, Kalair W, Hoque AN, Mungrue IN, Zhu Z and Husain M: Calcineurin-independent regulation of plasma membrane $\mathrm{Ca}^{2+}$ ATPase-4 in the vascular smooth muscle cell cycle. Am J Physiol Cell Physiol 285: C88-C95, 2003.

29. Chalmers JA, Martino TA, Tata N, Ralph MR, Sole MJ and Belsham DD: Vascular circadian rhythms in a mouse vascular smooth muscle cell line (MOVAS-1). Am J Physiol Regul Integr Comp Physiol 295: R1529-R1538, 2008.

30. Chalmers JA, Lin SY, Martino TA, Arab S, Liu P, Husain M, Sole MJ and Belsham DD: Diurnal profiling of neuroendocrine genes in murine heart, and shift in proopiomelanocortin gene expression with pressure-overload cardiac hypertrophy. J Mol Endocrinol 41: 117-124, 2008.

31. Choi KW, Park HJ, Jung DH, Kim TW, Park YM, Kim BO, Sohn EH, Moon EY, Um SH, Rhee DK and Pyo S: Inhibition of TNF- $\alpha$-induced adhesion molecule expression by diosgenin in mouse vascular smooth muscle cells via downregulation of the MAPK, Akt and NF- $\kappa$ B signaling pathways. Vascul Pharmacol 53: 273-280, 2010

32. Johnson KA,Polewski M and Terkeltaub RA: Transglutaminase 2 is central to induction of the arterial calcification program by smooth muscle cells. Circ Res 102: 529-537, 2008.

33. Lomri A, Marie PJ, Tran PV and Hott M: Characterization of endosteal osteoblastic cells isolated from mouse caudal vertebrae. Bone 9: 165-175, 1988.

34. MacRae VE, Davey MG, McTeir L, Narisawa S, Yadav MC, Millan JL and Farquharson C: Inhibition of PHOSPHO1 activity results in impaired skeletal mineralization during limb development of the chick. Bone 46: 1146-1155, 2010.
35. Farquharson C, Lester D, Seawright E, Jefferies D and Houston B: Microtubules are potential regulators of growth-plate chondrocyte differentiation and hypertrophy. Bone 25: 405-412, 1999.

36. Farquharson C, Berry JL, Mawer EB, Seawright E and Whitehead CC: Regulators of chondrocyte differentiation in tibial dyschondroplasia: an in vivo and in vitro study. Bone 17: 279-286, 1995 .

37. MacRae VE, Farquharson $\mathrm{C}$ and Ahmed SF: The restricted potential for recovery of growth plate chondrogenesis and longitudinal bone growth following exposure to pro-inflammatory cytokines. J Endocrinol 189: 319-328, 2006.

38. MacRae VE, Horvat S, Pells SC, Dale H, Collinson RS, Pitsillides AA, Ahmed SF and Farquharson C: Increased bone mass, altered trabecular architecture and modified growth plate organization in the growing skeleton of SOCS2 deficient mice. J Cell Physiol 218: 276-284, 2009.

39. Van Belle H: Alkaline phosphatase. I. Kinetics and inhibition by levamisole of purified isoenzymes from humans. Clin Chem 22: 972-976, 1976.

40. Register TC and Wuthier RE: Effect of pyrophosphate and two diphosphonates on ${ }^{45} \mathrm{Ca}$ and ${ }^{32} \mathrm{Pi}$ uptake and mineralization by matrix vesicle-enriched fractions and by hydroxyapatite. Bone 6 : 307-312, 1985.

41. Ju H, Gros R, You X, Tsang S, Husain M and Rabinovitch M: Conditional and targeted overexpression of vascular chymase causes hypertension in transgenic mice. Proc Natl Acad Sci USA 98: 7469-7474, 2001

42. You XM, Mungrue IN, Kalair W, Afroze T, Ravi B, Sadi AM, Gros R and Husain M: Conditional expression of a dominantnegative c-Myb in vascular smooth muscle cells inhibits arterial remodeling after injury. Circ Res 92: 314-321, 2003.

43. Gadeau AP, Chaulet H, Daret D, Kockx M, Daniel-Lamazière JM and Desgranges C: Time course of osteopontin, osteocalcin, and osteonectin accumulation and calcification after acute vessel wall injury. J Histochem Cytochem 49: 79-86, 2001.

44. Addison WN, Azari F, Sørensen ES, Kaartinen MT and McKee MD: Pyrophosphate inhibits mineralization of osteoblast cultures by binding to mineral, up-regulating osteopontin, and inhibiting alkaline phosphatase activity. J Biol Chem 282: 15872-15883, 2007.

45. Boskey AL, Doty SB, Kudryashov V, Mayer-Kuckuk P, Roy R and Binderman I: Modulation of extracellular matrix protein phosphorylation alters mineralization in differentiating chick limb-bud mesenchymal cell micromass cultures. Bone 42: 1061-1071, 2008

46. Shroff RC, McNair R, Skepper JN, Figg N, Schurgers LJ, Deanfield J, Rees L and Shanahan CM: Chronic mineral dysregulation promotes vascular smooth muscle cell adaptation and extracellular matrix calcification. J Am Soc Nephrol 21: $103-112,2010$ 